\title{
Nutrient uptake by a deposit-feeding enteropneust: nitrogenous sources
}

\author{
Drew A. Carey ${ }^{1, *}$, Lawrence M. Mayer ${ }^{2}$ \\ ${ }^{1}$ Earth and Environmental Sciences, Wesleyan University, Middletown, Connecticut 06457, USA \\ ${ }^{2}$ Department of Oceanography, University of Maine, Darling Marine Center, Walpole, Maine 04573, USA
}

\begin{abstract}
We measured carbon, nitrogen, protein, bacterial and microalgal abundance, and mineralspecific surface area in sediments from the feeding zone of undisturbed Saccoglossus kowalewskyi, as well as in their fresh egesta. Comparison of results using surficial material (>1 $\mathrm{mm}$ ) and the top $3 \mathrm{~mm}$ of sediments indicated ingestion of surficial material by the enteropneusts. Assuming the surficial sediment as a food source results in apparent absorption efficiencies of $15 \%$ for TOC, $35 \%$ for TON, $60 \%$ for protein and $86 \%$ for microalgae. The C:N ratio of the apparently absorbed material was 4.2 , consistent with an amino acid-rich diet. Protein-nitrogen uptake, however, accounted for only about $28 \%$ of total nitrogen absorption, indicating a dominant use of non-protein nitrogen. Bacterial and microalgal contributions to dietary nitrogen uptake were no more than $3 \%$ and $4 \%$ respectively. Active worms maintain 2 foraging areas with an average total foraging volume of $0.9 \mathrm{~cm}^{3}$ and a volume ingestion rate of 0.06 to $0.12 \mathrm{~cm}^{3}$ ind. ${ }^{-1} \mathrm{~h}^{-1}$ If the preferred feeding zone of these enteropneusts is the nitrogen-enriched surficial layer, we estimate that their feeding activities will deplete the available food resources every 8 to $16 \mathrm{~h}$ and they may rely on biological and tidal redistribution of surface material.
\end{abstract}

\section{INTRODUCTION}

Detritus food chains are commonly thought to be limited by the availability of nutritionally accessible nitrogen (e. g. Newell 1965, Fenchel \& Jørgensen 1977. Tenore 1977, Tenore 1983. Tenore et al. 1979, Tenore \& Chesney 1985). Yet little is known about the nature and source of nitrogenous materials used by heterotrophs in these food chains, particularly for marine deposit feeders. While non-living materials are clearly important to meet overall caloric needs (Cammen 1980, Lopez \& Levinton 1987), it is not clear whether they are necessary for nitrogenous needs (Rice et al. 1986). Further, if non-living organic nitrogen is important, it is not known if the nutritionally available materials are fresh proteins, protein degradation products, partially humified materials, or other compounds (Rice 1982, Rice \& Hanson 1984, Mayer 1989). Bowen (1980) found that non-protein amino acids constituted the nitrogen source for detritivorous fish and raised the question of whether such material would be important for invertebrate deposit-feeders. In this paper we report

- Present address: Thames Science Center, Gallows Lane, New London, Connecticut 06320, USA results of field experiments that suggest that detrital non-protein nitrogenous compounds may be the dominant dietary nitrogen source of a surface depositfeeding enteropneust.

At our sampling site, the enteropneust Saccoglossus kowalewskyi ingests surficial sediment from at least 2 areally distinct foraging areas and egests the sediment in an easily collected coil on the surface (for observations on coil production and collection see Carey \& Farrington 1989). This feeding behavior facilitates the analysis of absorption efficiencies of undisturbed worms feeding on natural sediments. It leaves in question, however, the exact sediment fraction ingested by an individual worm, necessitating a population-level approach to analyse absorption efficiencies. After initial trials evaluating uptake of individual worms, we designed a sampling scheme to measure the levels of nutrients in 2 distinct fractions of the surface sediments available to a population of S. kowalewsky and in fresh egesta collected from a sample of the same population.

\section{METHODS}

Sampling was conducted on an intertidal mudflat in Lowes Cove, Maine, USA, $\left(43^{\circ} 56^{\prime} \mathrm{N}, 69^{\circ} 35^{\prime} \mathrm{W}\right)$. Several 
aspects of the sediments and their organic matter have been described previously (Anderson et al. 1981, Mayer et al. 1985). After clearing relict egesta, we sampled surface sediments using 2 sampling methods and then collected fresh egesta as they appeared from 2 specific areas $\left(2500 \mathrm{~cm}^{2}\right)$ for several hours. On the following day, the methods of sampling were switched between the sites and surface sediments and egesta were sampled again.

Each sampling method was performed by a single person (collector) and collectors were then switched between sites. One collector used a plastic pipette held at an acute angle to the surface, collecting as thin a layer as possible - less than $1 \mathrm{~mm}$ ('surface layer'); the other collector used an identical plastic pipette held perpendicular to the sediment surface, which was used to homogenize and collect the top $3 \mathrm{~mm}$ of surface sediment. Fresh egesta were carefully pipetted off of the sediment surface; if they are collected immediately after egestion the discrete coils can easily be separated from the surface layer. Individual pipettings of surface sediments and egesta were separately pooled in preweighed $15 \mathrm{ml}$ centrifuge tubes until about $5 \mathrm{ml}$ of sediment was contained in a single tube - the amount needed for the analyses we performed.

Upon returning to the laboratory, we rinsed the samples with 2 parts distilled, filtered $(0.2 \mu \mathrm{m})$ water and 1 part filtered $(0.2 \mu \mathrm{m})$ seawater to reduce the salt content. The samples were vortexed with this wash and then centrifuged. The supernatant was pipetted off and subsamples were frozen and then freeze-dried. Protein analysis was carried out by the method of Mayer et al. (1986), which measures larger polypeptides amenable to protease hydrolysis. Protein is thus analytically defined here as enzymatically hydrolyzable polypeptides larger than 7 to 15 amino acid residues in length. Total organic carbon and nitrogen were analyzed with a Carlo Erba Model 1106 CHN analyzer after vapor phase acidification with $\mathrm{HCl}$ to remove calcium carbonate. Bacteria were counted by epifluorescence microscopy after (diamidinophenylindole) staining (DeFlaun \& Mayer 1983). Mineral-specific surface area was measured by nitrogen adsorption, after removal of organic coatings by hydrogen peroxide/sodium pyrophosphate treatment, using the 1-point BET method with a Quantachrome Monosorb analyzer (Mayer et al. 1988).

Subsamples of the centrifuged sediment were preserved with Lugol's solution and kept refrigerated in the dark. Six of these samples were suspended in $5 \mathrm{ml}$ distilled water and subsampled for direct microscopic counts and volume measurement of microalgal cells. Subsamples were dried and weighed to calculate cell abundance and biovolume per sediment dry weight.

\section{RESULTS}

Total organic carbon and nitrogen pooled for both sites were 24 and $27 \%$ higher, respectively, in the surface layer than in the top 0 to $3 \mathrm{~mm}$ (Fig. $1 \mathrm{~A}, \mathrm{~B}$ ). The $\mathrm{C}: \mathrm{N}$ ratios (wt/wt) of the 2 sediment collections were not significantly different $(\bar{x}=10.3 \pm 0.8, n=8)$.

Protein was enriched by $23 \%$ in the surface layer (Fig. 1C). Protein concentrations were at the low end of the range for surface $\mathrm{cm}$ samples from various parts of Lowes Cove (Mayer unpubl.). The protein measured by our method in the surface layer accounted for $17 \%$ of the total nitrogen in this layer (assuming the standard relationship: protein-nitrogen $=0.16 \times$ protein). This ratio is as high as we have measured for Gulf of Maine sediments (Mayer et al. 1988) indicating relatively high nutritional quality despite the low bulk organic content (Mayer 1989).

The 2 sediment zones were significantly different at both collection sites for carbon and nitrogen (Table 1A). The consistency of the difference across zones indicates reproducibility of our collection methods. Protein was not significantly different at one site (Table 1A) which suggests that at this site, protein is less enriched in the surface layer than non-protein nitrogen. However the pooled results for both sites show similar enrichment for protein and nitrogen (Fig. 1). Surface sediments $(<1 \mathrm{~mm})$ were significantly different from fresh egesta for nitrogen and protein at both sites (Table 1B). Organic carbon was significantly higher in the egesta than in the 0 to $3 \mathrm{~mm}$ layer (Table $1 \mathrm{C}$ ).

The minimum absorption efficiencies, defined here as the difference between egesta and food source divided by the food source, for carbon and nitrogen were 15 and $35 \%$, respectively. This calculation assumes that the enriched surface layer is ingested by Saccoglossus kowalewskyi exactly like our collection method (Fig. 1). With this assumption, the material removed during gut passage has $\mathrm{C}: \mathrm{N}=4.2$. Although the minimum absorption efficiency of protein by $S$. kowalewskyi was $60 \%$, the protein-nitrogen absorption averaged only $28 \%$ of the total nitrogen lost during gut passage.

Bacteria and microalgae contribute negligibly to the standing stock of protein in these sediments, and do not account for a significant fraction of the assimilated protein or total nitrogen (compare Fig. 1C with 1D and 1E). Assuming Rublee's (1982) conversion factor of $0.033 \mathrm{gN}$ ( $\mathrm{ml}$ biovolume) ${ }^{-1}$, and an average cell volume of $0.2 \mu^{3}$ (consistent with DeFlaun \& Mayer 1983), bacteria comprise no more than 5 to $10 \%$ of the protein-nitrogen. The inconsistent apparent net loss of bacteria during gut passage (Fig. 1D) in some of the experiments accounted for no more than $9 \%$ of the assimilated protein-nitrogen, or $3 \%$ of the assimilated total nitrogen. 

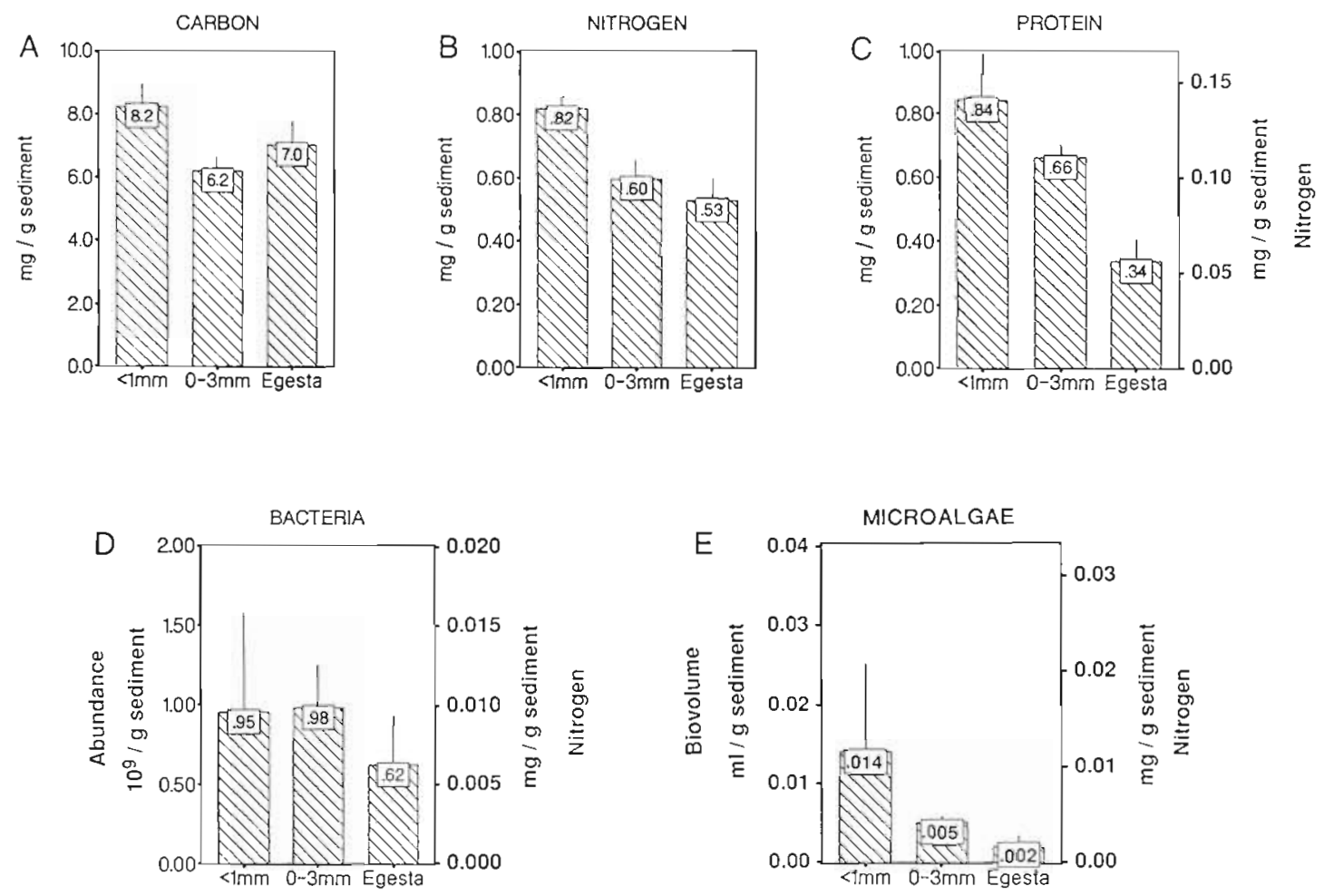

Fig. 1. All nutrients measured in surface sediments $(<1 \mathrm{~mm}, 0-3 \mathrm{~mm})$ and egesta of Saccoglossus kowalewskyi in Lowes Cove, Maine, USA. Bars represent 1 standard deviation. (A) Total organic carbon. (B) Total nitrogen. (C) Scale on left: protein. Scale on right: protein-nitrogen ( $=0.16 \times$ protein). (D) Scale on left: bacterial abundance. Numbers on bars refer to abundance means from 4 samples. Scale on right: nitrogen calculated from cell numbers assuming $0.66 \times 10^{-14} \mathrm{~g} \mathrm{~N}$ cell ${ }^{-1}$ (E) Scale of left: biovolume of microalgae. Scale on right: nitrogen calculated from biovolume measurements, biomass:biovolume ratio (Eppley et al. 1970) and a $\mathrm{C}: \mathrm{N}$ ratio of 6 . Microalgal biovolume calculated from measurements of cell sizes and direct counts of microalgae. Numbers on bars refer to nitrogen means for 4 samples

Microalgal biomass calculated from measured biovolumes (Eppley et al. 1970: $\log \mathrm{pg} \mathrm{C}=0.76 \times \log \mathrm{V}$ - 0.352 ) comprised $8 \%$ of the protein-nitrogen (Fig. $1 \mathrm{E})$. The apparent loss of microalgae during ingestion was substantial (Fig. 1E, mean of $87 \%$ from 4 paired samples of surface layer and egesta) but accounted for less than $13 \%$ of the assimilated protein-nitrogen, or about $4 \%$ of the assimilated total nitrogen. The apparent loss of algae may also have been due to selection against the relatively large diatom cells, as empty frustules counted in one egesta sample could not account for the loss of live cells from the paired surface sample.

\section{DISCUSSION}

\section{Surface layer ingestion}

The higher carbon contents of the egesta compared to the 0 to $3 \mathrm{~mm}$ zone would appear to exclude intake of the top $3 \mathrm{~mm}$ of sediment as a bulk food source for Saccoglossus kowalewskyi during these experiments (Fig. 1A). In steady state, it is unlikely that this entero- pneust produces carbon during gut passage. While we have not demonstrated conclusively that our surface samplings are congruent with the ingested fraction, the bulk nutrient concentration of this layer is sufficient to support a positive uptake of carbon and nitrogen. This zone of feeding is also consistent with the feeding mechanism of the animal, which employs a ciliated proboscis that is extended out of the burrow onto the sediment surface. The proboscis is then dragged back into the burrow with particles that adhere to the mucociliary epithelium of this muscular feeding organ (Knight-Jones 1953, Carey 1989).

Alternate possibilities to explain these data are that the enteropneust is showing particle selection from a thicker layer of sediment of mixing enriched surface layers with subsurface sediment; while both of these may occur they are not consistent with laboratory observations with marked sediments. Laboratory and field observations (Carey 1989, unpubl.) show that marked sediments placed sequentially in $1 \mathrm{~mm}$ layers on the surface are egested sequentially without mixing. In addition, surface area measurements for mineral grains from a top $3 \mathrm{~mm}$-egesta collection pair gave 
Table 1. Two-way Analyses of Variance. Summary of F statistics. (A, B) Calculated on each site separately; (C,D) calculated on each collector separately. " $p<0.05 ; \cdots p<0.01 ; \cdots p<0.001$; NS: not significant

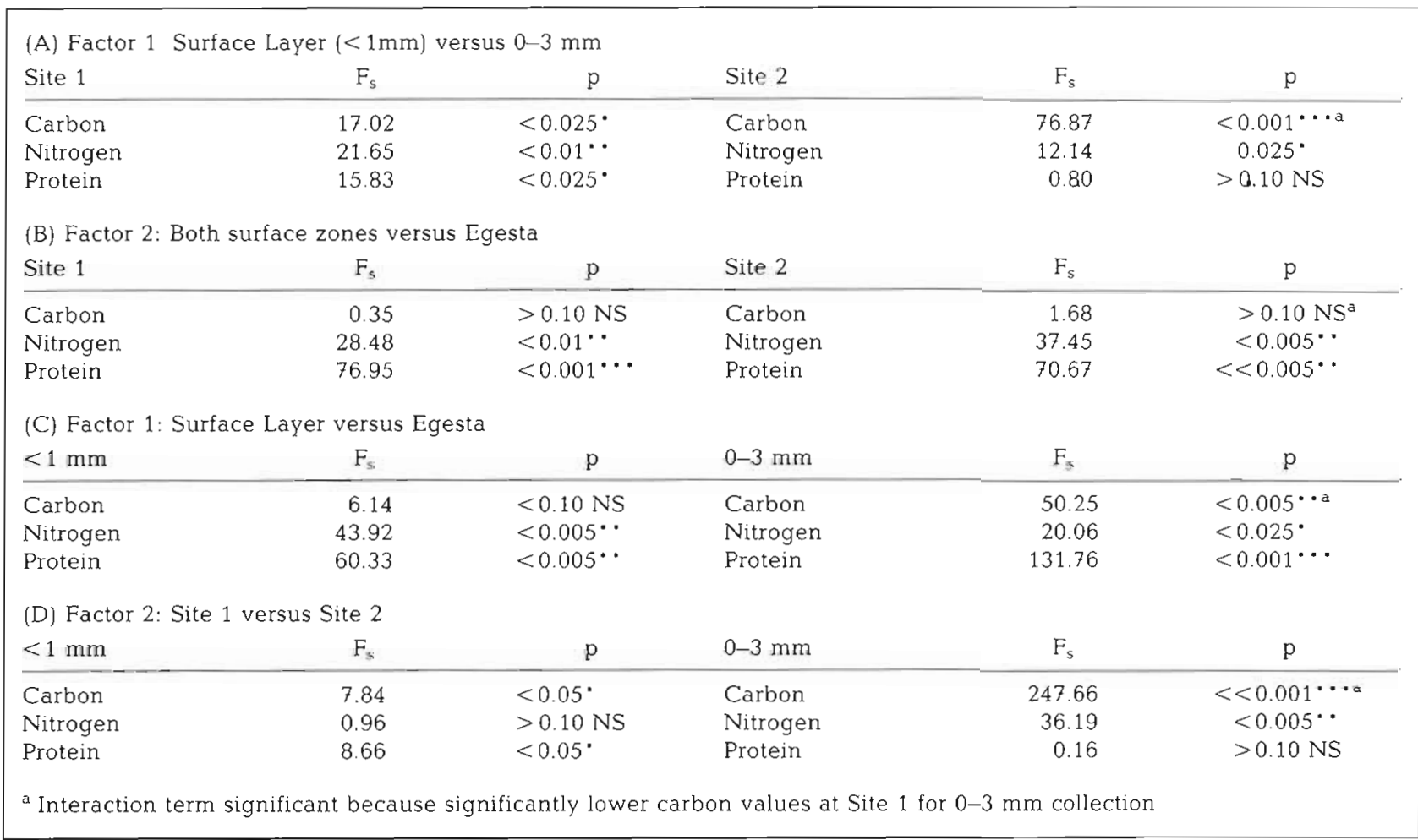

values of 10.3 and $9.7 \mathrm{~m}^{2} \mathrm{~g}^{-1}$ dry sediment, respectively, indicating that any selection of mineral grains from the top $3 \mathrm{~mm}$ was not on the basis of particle size. This finding is consistent with other reports of nonselectivity in enteropneusts (Knight-Jones 1953, Dobbs \& Guckert 1988).

We conclude that Saccoglossus kowalewskyi is likely feeding primarily on a very loose layer of particles about $1 \mathrm{~mm}$ thick. Some selection may occur, most likely through variations in mechanical or chemical adherence to the feeding organ (Self \& Jumars 1978 , 1988). While we have no evidence to support either enrichment or dilution of organic content in the ingested fraction relative to the sampled fraction, common sense leads us to suspect that the sampled material most likely represents a minimum value for nutritional quality. This food source is also consistent with the regression of carbon ingestion rates relative to body size of polychaetes (Cammen 1986), assuming a mean body weight for S. kowalewskyi of $100 \mathrm{mg}^{-1} \mathrm{in}^{-1}$ (Carey unpubl.) and mean bulk ingestion rates of $720 \mathrm{mg}$ ind $\mathrm{d}^{-1} \mathrm{~d}^{-1}$ (Carey \& Clough unpubl.). To the extent that we have measured the food quality correctly, there are interesting implications of the apparent quality of the assimilated material. We emphasize, however, that the actual food quality ingested may be dominated by some preferentially selected material, obviating our interpretations.

The apparently low contribution of protein nitrogen to the total nitrogen apparently assimilated by Saccoglossus kowalewskyi indicates the extensive use of non-protein nitrogenous compounds. We have found the same pattern of loss of protein and total nitrogen in downcore diagenesis of nitrogen (Mayer unpubl.). Furthermore, in spite of different methods of protein measurement, our finding is also in accord with Bowen's (1980) conclusion that the detritivorous fish Sarotheradon mossambicus receives most of its diet from non-protein amino acids. The bulk of the nitrogen absorption that we observed may be in the form of shorter polypeptide compounds. Mayer (1989) has shown that adsorbed or dissolved monomeric amino acids are unlikely to provide a significant food source for detritivores and our protein technique measures peptides larger than 7 to 15 amino acid residues in length. Thus, if the non-protein nitrogen is in the form of amino acids, they are likely present as oligopeptides composed of less than 15 amino acid residues. These short polypeptides are likely to be degradation products of proteins.

Also of note is the apparently low $C: N$ ratio of the assimilated material (4.2), which would represent a 
food very rich in nitrogen. This finding is consistent with data of Kristensen \& Blackburn (1987) data showing that material of $\mathrm{C}: \mathrm{N}=4$ was the immediately bioavailable substrate in sediment organic matter decomposition experiments. Nitrogen is often considered to be the limiting nutrient in detritivore nutrition (Newell 1965, Fenchel \& Jørgensen 1977, Tenore 1977. Tenore et al. 1979, Tenore \& Chesney 1985). If correct, this assimilation stoichiometry suggests that Saccoglossus kowalewskyi may act as a deposit feeder, but that these deposit feeders subsist on a diet that is as rich in nitrogenous compounds as that of a carnivore.

If actively feeding worms confine the majority of their intake to the nitrogen-enriched top $\mathrm{mm}$ of sediment, they will exhaust their immediate foraging volumes in 4 to $8 \mathrm{~h}$. We estimate nitrogen consumption rates of $21 \mathrm{mg} \mathrm{m}^{-2} \mathrm{~d}^{-1}$ for average field densities of Saccoglossus kowalewskyi in Lowes Cove 100 ind. $\mathrm{m}^{-2}$ ) based on sediment processing rates measured during summer low tides $\left(720 \mathrm{mg}\right.$ ind. ${ }^{-1} \mathrm{~d}^{-1}$, Carey \& Clough unpubl.). The mean foraging volume of Lowes Cove worms is estimated at $0.45 \mathrm{~cm}^{3}$ (foraging area $=$ $4.5 \mathrm{~cm}^{2}$, Carey unpubl. obs.; foraging depth $=1.0 \mathrm{~mm}$ ) and we calculate a volume ingestion rate of 0.06 to $0.12 \mathrm{~cm}^{3}$ ind. ${ }^{-1} \mathrm{~h}^{-1}$ (assuming a surface sediment dry weight range of 250 to $500 \mathrm{mg} \mathrm{cm}^{-3}$ ). Unless organic matter input to the feeding zone keeps pace with this rate, the worms must either extend their foraging radius or depth (Miller et al. 1984). If surface feeders establish several foraging areas, they can increase foraging radii through burrow extension without increasing the risk of predation on overextended feeding organs.

In this habitat, many individuals of Saccoglossus kowalewskyi simultaneously maintain 2 foraging areas on the sediment surface (Carey \& Clough unpubl, obs.). If surface sediments are a preferred food source, this behavior may represent a response to sediment renewal frequencies (Miller et al. 1984). Surface sediment must be renewed (including deposition, wave and tidal redistribution, biological mixing and in situ production) every 8 to $16 \mathrm{~h}$ to permit maintenance of 2 foraging areas at these population densities, egestion rates, and feeding depths. These renewal times are similar to tidal exchange frequencies, and although we have only measured nitrogen uptake in Lowes Cove at low tide, this renewal frequency may represent a limit on the nitrogen uptake of these surface feeding worms in this environment.

Acknowledgements. We thank $\mathrm{L}$. Schick for chemical analyses and C. Gregory for cell counting. This work was supported by NSF (OCE 8700358 and ISP 8011448 to L.M.M.) and Wesleyan University (to D.A.C.). Contribution No. 212 of the Darling Marine Center

\section{LITERATURE CITED}

Anderson, F. E., Black, L., Watling, L. E., Mook, W M., Mayer, L. M. (1981). A temporal and spatial study of mudflat erosion and deposition. J. sedim. Petrol. 51: 729-736

Bowen, S. H. (1980). Detrital nonprotein amino acids are the key to rapid growth of Tilapia in Lake Valencia, Venezuela. Science 207: 1216-1218

Cammen, L. M. (1980). The significance of microbial carbon in the nutrition of the deposit feeding polychaete Nereis succinea. Mar. Biol. 61. 9-20

Cammen, L. M. (1987). Polychaetes. In: Pandian, T. J., Vernberg, F. J. (eds.) Animal energetics. Academic Press, New York, p. $217-260$

Carey, D. A. (1989). Fluorometric detection of tracer particles used to study animal-particle dynamics. Limnol. Oceanogr. 34: 630-635

Carey, D. A., Farrington, J. W. (1989). Polycyclic aromatic hydrocarbons in Saccoglossus kowalewskyi (Agassiz). Estuar. coast Shelf Sci. 29: 97-113

DeFlaun, M. F., Mayer, L. M. (1983). Relationships between bacteria and grain surfaces in intertidal sediments. Limnol. Oceanogr. 28: 873-881

Dobbs, F. C., Guckert, J. B. (1988). Microbial food resources of the macrofaunal-deposit feeder Ptychodera bahamensis (Hemichordata: Enteropneusta). Mar. Ecol. Prog. Ser. 45: $127-136$

Eppley, R. W., Reid, F. H., Strickland, J. D. H. (1970). Estimates of phytoplankton crop size, growth rate, and primary production. In: Strickland, J. D. H. (ed.) The ecology of the plankton off La Jolla, California, in the period April through September, 1967. Part 3. Bull. Scripps Inst. Oceanogr $17 \cdot 33-42$

Fenchel, T M., Jørgensen, B. B. (1977). Detritus food chains of aquatic ecosystems: the role of bacteria. Adv. microb. Ecol. 1: $1-58$

Knight-Jones, E. W. (1953). Feeding in Saccoglossus (Enteropneusta). Proc. Zool. Soc. Lond. 123: 637-654

Kristensen, E., Blackburn, T H. (1987). The fate of carbon and nitrogen in experimental marine sediment systems: influence of bioturbation and anoxia. J. mar. Res. 45: 231-257

Lopez, G. R., Levinton, J. S. (1987). Ecology of deposit-feeding animals in marine sediments. Q. Rev. Biol. 62: 235-260

Mayer, L. M. (1989). The nature and determination of nonliving sedimentary organic matter as a food source for deposit feeders. In: Lopez, G. R., Taghon, G. L., Levinton, J. S. (eds.) The ecology of marine deposit feeders. Springer-Verlag, New York, p. 98-113

Mayer, L. M., Macko, S. A., Cammen, L. (1988). Provenance, concentrations and nature of sedimentary organic nitrogen in the Gulf of Maine. Mar. Chem. 25: 291-304

Mayer, L. M., Rahaim, P. T., Guerin, W., Macko, S. A., Watling, L., Anderson, F. E. (1985). Biological and granulometric controls on sedimentary organic matter of an intertidal mudflat. Estuar. coast. Shelf Sci. 20: 491-503

Mayer, L. M., Schick, L. L., Setchell, F. W. (1986). Measurement of protein in nearshore marine sediments. Mar. Ecol. Prog. Ser. 30: 159-165

Miller, D. C., Jumars, P. A., Nowell, A. R. M. (1984). Effects of sediment transport on deposit feeding: scaling arguments. Limnol. Oceanogr. 29: 1202-1217

Newell, R. C. (1965). The role of detritus in the nutrition of two marine deposit feeders, the prosobranch Hydrobia ulvae and the bivalve Macoma balthica. Proc. Zool. Soc. Lond. 144: $25-45$

Rice, D. L. (1982). The detritus nitrogen problem. New obser- 
vations and perspectives from organic geochemistry. Mar Ecol. Prog. Ser. 9:153-162

Rice, D. L., Bianchi, T S., Roper, E. H. (1986). Experimental studies of sediment reworking and growth of Scoloplos spp. (Orbinidae: Polychaeta). Mar Ecol. Prog. Ser. 30: 9-19

Rice, D. L., Hanson, R. B. (1984). A kinetic model for detritus nitrogen: role of the associated bacteria in nitrogen accumulation. Bull. mar. Sci. 35: 326-340

Rublee, P. A. (1982). Seasonal distribution of bacteria in salt marsh sediments in North Carolina. Estuar, coast. Shelf Sci. 15: $67-74$

Self, R. F. L., Jumars, P. A. (1978). New resource axes for deposit feeders? J. mar. Res. 36: 627-641

Self, R. F. L., Jumars, P. A. (1988). Cross-phyletic patterns of

This article was presented by Professor K. R. Tenore, Solomons, Maryland, USA particle selection by deposit feeders. J. mar Res. 46 $119-143$

Tenore, K. R. (1977). Growth of Capitella capitata cultured on various levels of detritus derived from different sources. Limnol. Oceanogr. 22: 936-941

Tenore, K. R. (1983). What controls the availability of detritus derived from vascular plants: organic nitrogen enrichment or caloric availability? Mar. Ecol. Prog. Ser. 10: 307-309

Tenore, K. R., Chesney, E. (1985). The interaction of rate of food supply and population density upon the bioenergetics of the opportunistic polychaete, Capitella capitata (Type I). Limnol. Oceanogr. 30: 1188-1195

Tenore, K. R., Hanson, R. B., Dornseif, B. E., Wiederhold, C. N (1979). The effect of organic nitrogen supplement on the utilization of different sources of detritus. Limnol. Oceanogr. 24: 350-355

Manuscript first received: August 20, 1989

Revised version accepted: December 20, 1989 